\title{
Green energy products in the United Kingdom, Germany and Finland
}

\author{
Aira Hast ${ }^{1, a}$, Liisa McDermott ${ }^{2}$, Marja Järvelä ${ }^{2}$ and Sanna Syri ${ }^{1}$ \\ ${ }^{1}$ Department of Energy Technology, Aalto University, Otakaari 4, 00076 Aalto, Finland \\ ${ }^{2}$ Department of Social Sciences and Philosophy, University of Jyväskylä, P.O. Box 35, \\ 40014, Finland
}

\begin{abstract}
In liberalized electricity markets, suppliers are offering several kinds of voluntary green electricity products marketed as environmentally friendly. This paper focuses on the development of these voluntary markets at household level in the UK, Germany and Finland. Since there are already existing renewable energy policies regulating and encouraging the use of renewable energy, it is important to consider whether voluntary products offer real additional benefits above these policies. Problems such as double counting or re-marketing hydropower produced in existing plants are identified.

According to our study, the demand varies between countries: in Germany the number of green electricity customers has increased and is also higher than in the UK or Finland. Typically the average additional cost to consumer from buying green electricity product instead of standard electricity product is in the range of $0-5 \%$ in all studied countries, although the level of price premium depends on several factors like electricity consumption. Case study of Finland and literature show that the impacts of green energy are not solely environmental. Renewable energy can benefit local public policy.
\end{abstract}

\section{Introduction}

Liberalization of electricity markets has made it possible for customers to choose their electricity supplier and product freely according to their preferences. Electricity production is a significant source of greenhouse gas emissions causing climate change and its environmental aspects are also taken into consideration by many customers. Suppliers are offering differentiated products in order to better meet consumers' preferences and environmental aspects are thus also used in marketing in addition to competition only on price. As a result, several kinds of voluntary green electricity products are available for customers nowadays. This study focuses on green electricity markets in three European countries: the United Kingdom, Germany and Finland.

The term green electricity is not, however, clearly defined. Often it means that the electricity is at least partly generated from renewable sources. Yet, other kinds of mechanisms like green funds or carbon offsetting can be included, and the transparency and quality of products can vary significantly.

\footnotetext{
${ }^{a}$ Corresponding author: aira.hast@aalto.fi
}

This is an Open Access article distributed under the terms of the Creative Commons Attribution License 4.0, which permits unrestricted use, distribution, and reproduction in any medium, provided the original work is properly cited. 
Since there are renewable energy policies concerning the use of renewable energy, it is important to consider whether voluntary products offer real additional benefits above legally set obligations [1].

Green electricity products usually cost slightly more than standard electricity products. According to studies, many customers are, however, willing to pay more for green electricity [2,3]. Yet, the actual take up is often lower than the stated willingness to pay. Different kinds of reasons, such as lack of trust and old habits, have been identified as barriers to purchasing green electricity. The development of the numbers of green electricity customers and the levels of the price premiums are studied in this paper.

Renewable energy can also have other than environmental impacts. We review literature on local policies to encourage renewable energy production and benefits gained from local renewable energy projects. Finland is viewed in more detailed case study including Vaasa and Joensuu. These case studies indicate that energy technology markets might proceed easier than renewable electricity markets. The benefits of the energy technology business in Vaasa and lower heating costs in Joensuu benefit the local economy which benefits local public policy in the area.

\section{Renewable energy policies and voluntary green electricity markets}

Electricity production from renewable energy sources is regulated and encouraged both in EU and at national level in the studied countries. EU has set binding targets for Member States concerning the share of renewable energy in gross final consumption, by 2020 the share of renewables should be $38 \%$ in Finland, $18 \%$ in Germany and 15\% in the UK [4]. Electricity sector has an important role in meeting this target set for total energy use. Directives 2003/54/EC and 2009/28/EC require that Member States have to provide suppliers with possibility to prove the origin of renewable energy and that suppliers have to provide customer with information on the sources from which the electricity is generated $[4,5]$.

At national level Member States can choose means to achieve the requirements set in Directives and there are various national programs and laws to encourage the use of renewable energy. In the UK, the Renewable Obligation (RO) was initiated in 2002 and it sets annual requirements for suppliers to buy a certain share of electricity from renewable energy sources [6]. There is a relatively strong support system for renewable energy in Germany. Support is based on the German Renewable Energy Sources Act (Erneuerbare-Energien-Gesetz EEG) which defines the use of financial instruments like feed-in tariffs, investment support and tax exemptions for renewable energy. It also sets rules for selling of renewable energy and forbids multiple sale of renewable energy [7]. In Finland feed-in tariffs for biogas and wind power production were initiated in 2010 [8].

The renewable energy policies concern all suppliers and not only suppliers that offer differentiated products like green electricity. In the UK, where suppliers are obliged to purchase specific share of renewable electricity, there is a risk that some suppliers only aim at meeting the minimum requirements of the RO system and sell the already required renewable electricity as a voluntary green electricity product. Thus the environmental benefits of renewable energy are double counted and assigning the required renewable electricity to green tariff customers does not have any influence on the overall energy $\operatorname{mix}[1,9-11]$.

In Germany the multiple sale of renewable energy is forbid in the EEG (Sect. 56) and renewable energy, sold as a voluntary green electricity product, cannot benefit from feed-in tariffs. Feed-in tariffs set a minimum price for renewable energy in Germany and it is unlikely that the producers sell renewable electricity to suppliers of green electricity unless they earn more money that way than from the feed-in tariffs. In order to keep the prices low, many green electricity suppliers buy their renewable electricity from abroad, where power plants cannot anyway benefit from the EEG. This renewable electricity is very often hydropower that originates from power plants that have been built long time ago. This kind of imported green power is therefore unlikely to create additional demand for electricity from renewable sources and for new renewable energy capacity [1,3, 12-14]. 
In Finland, the majority of electricity in green electricity products is produced with hydro or wind $[1,15]$. The existing hydropower capacity is large in Nordic electricity market area and there is thus a risk that no real environmental benefits are created. In addition, some suppliers do not provide transparent information on the impacts, which is why it is difficult, especially for the consumers, to assess the impacts. Earlier double counting of renewable energy was possible in Finland because of several coexisting systems to verify the origin of renewable energy. The legislation concerning the origin of electricity was recently changed in Finland and in order to prevent double counting, only one method to prove the origin of renewable energy should be used [1].

Green electricity products can also include problems related to marketing, and many suppliers do not provide enough information about how they use the price premiums and what kinds of real impacts the green electricity purchase has. This reduces the market transparency significantly. There are voluntary labels for green electricity products in which the products are assessed by third party. Labels can also set for example sustainability criteria for the electricity production or require investments in new renewable energy capacity $[1,16,17]$. The costs of renewable energy policies are at least partly passed on to all electricity customers i.e. also the price of standard electricity products is influenced by renewable energy policies. Increased renewable energy use can be seen as a public good and voluntary ways, such as green electricity markets, to deliver it can also have challenges like strong incentive to free-ride or higher unit costs than in a situation where costs would be distributed to all customers $[18,19]$. Special attention should therefore be paid on designing efficient interfacebetween policies and voluntary green electricity markets sothat both the additional benefits and costs are taken into consideration.

\section{Number of green electricity customers}

In this section, the development of the number of customers is studied and factors influencing the demand are discussed based on literature. Several studies $[2,18,20]$ have found that the actual participation is lower than the stated willingness to pay for green electricity. The estimates of the numbers of household electricity customers in studied countries are presented in Fig. 1 (bars). The numbers of customers are not always publicly available and estimates in Fig. 1 are collected from several different sources. It should also be noted that some bars (Germany and the UK before 2008) indicate the number of all customers and some bars only the number of customers of labeled products (Finland and the UK after 2010). The curves indicate the number of customers compared to the population of the country.

Fig. 1 shows that the demand in Germany has increased rapidly after 2006 but similar change cannot be seen in other countries. The number of green electricity sold as having "Ekoenergia" -label has dropped in Finland after 2010 because the label changed their criteria and all products did not fulfill them anymore. Because of the small population of Finland, this had significant influence to the demand compared to population (curve in Fig. 1). In 2011 the demand compared to population was higher in Germany than in the UK or Finland.

There is a large gap between the stated willingness to pay and actual uptake of green tariffs in the UK. Lack of trust, consumer confusion and lack of supply have been identified as barriers to purchase of green electricity. People are not necessarily aware of the green tariffs or are slow to buy them. There are several kinds of tariffs offered, some of them linked to renewable energy tariffs and some of them not linking to supply of energy from renewable sources as consumers usually associate these tariffs. In addition, green energy market is poorly defined in the UK, and complexities of constructing meaningful additional green source tariffs under the ROC system exist. Competition in electricity markets in the UK is very price-driven which can also explain the low demand [9, 17, 27-29].

There are studies that report relatively high customer willingness to pay for green electricity in Germany [2, 3], however, many practical barriers exist; customers may not want to change their electricity supplier or see the effort that it could require. Strong supply-side government support for 


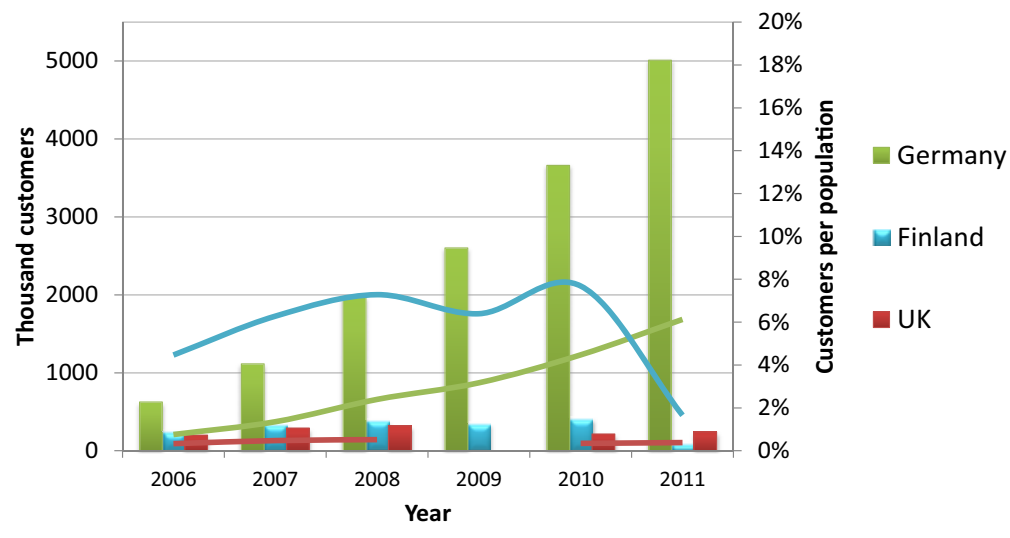

Figure 1. Number of green electricity customers in the UK, Germany and Finland (bars) and the number of customers compared to the population (curves) $[9,14,17,21-26]$.

renewable generation has also limited the green power market [17]. The existing market potential for green electricity is, however, rather large and it is for example found that the current default electricity mix does not correspond to current customer preferences [2].

Study on electricity markets in Finland [20] shows that several factors, such as environmental attitudes, knowledge about electricity markets and household characteristics, are simultaneously affecting consumer behavior. Lack of trust, old habits and need for effort in order to buy green energy have been identified as barriers to actual purchase of green electricity in Finland [20].

\section{Price premiums}

The price of green electricity is often mentioned as an important factor influencing the uptake even if price is clearly not the only factor that affects demand [17, 30, 31]. It is usually assumed that green electricity is more expensive than standard electricity product, in this section the levels of price premiums are estimated (Table 1). It should be noted that the premiums depend on several factors like region, electricity consumption, current discounts and other characteristics of the product (payment option, price guarantees and whether package tariffs with fixed electricity purchase are included).

As can be seen from Table 1, the ranges of price premiums are quite wide and they also include negative values, so green electricity product is in some cases cheaper than standard electricity product. In the UK and Germany, the mean values of price premiums are typically in the range of $0-5 \%$. Also in Finland the mean price of green electricity products is $0-2 \%$ higher than the mean price of standard electricity products. However, when only the 30 cheapest products were considered, the mean price of green electricity products was lower than the mean price of standard electricity products. The cheapest green electricity products were considerably cheaper than the cheapest standard electricity products in Finland.

\section{Green energy production and local governments}

In this section we study renewable energy in a wider context according to the literature review and the case study of Joensuu and Vaasa. In Joensuu the prerequisites of renewable energy were: rising energy prices, regional policy, cooperation, expertise in forestry and small and medium sized actors [1]. Vaasa has also long traditions in international relations, expertise in metal and engineering works and they have traditions in entrepreneurship. In Vaasa this has lead to international energy 
Table 1. Price premiums of green electricity at different levels of annual electricity consumption. Negative premium indicates that green electricity product is cheaper than standard electricity product. Different levels of electricity consumption were studied because household electricity consumption varies between countries (e.g. in Finland electric heating is quite common in detached houses, which is why high annual consumption is studied, in the UK the dual fuel option (including electricity and gas) is viewed because majority of the households are heated by gas).

\begin{tabular}{|c|c|c|c|c|}
\hline \multirow{3}{*}{ Country } & \multicolumn{3}{|c|}{ Own calculations } & \multirow{3}{*}{$\begin{array}{l}\text { Other studies } \\
\text { Price premium }\end{array}$} \\
\hline & \multirow{2}{*}{$\begin{array}{l}\text { Electricity } \\
\text { consumption } \\
\text { [kWh/year] }\end{array}$} & \multicolumn{2}{|c|}{ Price premium [\%] } & \\
\hline & & Range & Mean & \\
\hline \multirow{3}{*}{$\begin{array}{l}\text { UK }^{1} \\
\text { [suppliers' websites] }\end{array}$} & 2100 & $-7-6 ;(6-13)$ & $1 ;(10)$ & \multirow{3}{*}{$\begin{array}{l}0-15 \% \text { (majority } 2-10 \%)[17] \\
2 \%[9] \\
0-15 \% \text { (majority around } 5 \% \text { ) [21] }\end{array}$} \\
\hline & $3300^{2}$ & $\begin{array}{l}0-8 ;(8-16) \\
{[3-9]}\end{array}$ & $\begin{array}{l}3 ;(13) \\
{[7]}\end{array}$ & \\
\hline & 5100 & $0-10 ;(8-18)$ & $4 ;(14)$ & \\
\hline Germany $^{3}$ & 1800 & $-1-10$ & 5 & $5-10 \%$ (pure hydro) [3] \\
\hline \multirow{3}{*}{$\begin{array}{l}\text { [suppliers' websites] } \\
\text { [34-36] }\end{array}$} & 2500 & $-2-8$ & 3 & \multirow{3}{*}{$\begin{array}{l}15-35 \% \text { (CHP, renewables) [3] } \\
10-40 \% \text { (100\% renewables) [3] } \\
10-30 \% \text { (mean 22\%) [17] }\end{array}$} \\
\hline & 4000 & $-1-8$ & 2 & \\
\hline & 5600 & $-1-9$ & 2 & \\
\hline \multirow{4}{*}{$\begin{array}{l}\text { Finland }^{4} \\
\text { [suppliers' websites] } \\
\text { [37] }\end{array}$} & 2000 & $-16 ;[-7] ;(0)$ & & \multirow{4}{*}{$\begin{array}{l}3-12 \%[38] \\
5 \%, \text { butsometimes green electricity } \\
\text { productis cheaper than standard } \\
\text { electricity product [15] } \\
\text { Modest, some green electricity products } \\
\text { can be cheaper than standard electricity } \\
\text { [17] }\end{array}$} \\
\hline & 4000 & $-16 \cdot[-6] \cdot(1)$ & & \\
\hline & & & & \\
\hline & 20,000 & $-10 ;[-2] ;(2)$ & & \\
\hline
\end{tabular}

technology business. Local renewable energy production can also have other than environmental impacts, it can for example support local economic development and create jobs. Local policies to support renewable energy projects are also discussed. These case studies are a part of a larger project where, in addition to the Finnish cities introduced here, research was done also in two cities in Texas in the U.S.A. and two other cities, Espoo and Imatra, in Finland. In the U.S. the cities were Austin and San Antonio. This case study is only about Vaasa and Joensuu because they are similar to each other - giving a better view on how renewable energy has proceeded in some cities. The research questions were: How did renewable energy become more common? Why did renewable energy become more common? The research was done by interviewing people in Vaasa and by reading strategy documents written by the city of Vaasa and the provincial government of Ostrobothnia. The people interviewed were city managers of Vaasa, the provincial government of Ostrobothnia and business leaders in energy technology businesses in Vaasa. Altogether there was eight interviews. The supporting documents [3946] are listed in the sources. The case study of Joensuu has been written in more detail in a previous

\footnotetext{
114 regions in the UK were studied; premium is the difference between the cheapest green and the cheapest standard electricity product (compared to the price of the cheapest standard electricity product). The mean is the arithmetic mean of the premiums in different regions. Two payment options "Monthly direct debit" (most common) and "Cash or cheque" (in brackets) were studied. 2 Dual fuel (in square brackets) option includes 3,300 kWh electricity and 16,500 kWh gas.

315 regions in Germany were studied and as in the case of the UK, premiumis calculated as the difference between the cheapest green and the cheapest standard electricity product in each region. Different options (package tariffs, other discounts and price guarantees) were considered so that the green and standard electricity products, which were compared to each other, meet the same criteria.

${ }^{4}$ We found that the premiums did not differ significantly between regions in Finland. The total number of products was 70 (green and standard products). We compared the prices of the cheapest green and the cheapest standard electricity products, the means of green and of standard electricity when only the 30 cheapest products were taken into consideration (in square brackets) and the means of green and of standard electricity products when all 70 products were studied (in brackets).
} 
paper [1]. Therefore only the main results will be introduced here, details can be found from the paper "Impacts of green electricity markets in the United Kingdom, Germany and Finland" [1].

Even with a wide selection of useful policies, none of the policies can suit all cities and towns, and it is pointed out by IEA [48] that local conditions should be widely taken into consideration in order to determine the most appropriate policies. This came up in the case study of Joensuu and Vaasa. Local conditions and industries determine what renewable energy technology gains acceptance because they can get the acceptance of the already existing industries. In the area of Joensuu traditions in forestry has lead to the use of bioenergy. In Joensuu there is also a lot of education and research related to forestry which seems to support the use of bioenergy [1]. In Vaasa the traditional industry was metal and engineering works. According to the interviews Vaasa has also long traditions in entrepreneurship and international relations dating back to the 1600s which creates good prerequisites for international business. Today in Vaasa there is a lot of education and research related to energy, engineering and metal works $[39,40]$. Vaasa's main industry was traditionally metal and engineering works, this seems to have evolved into energy technology business in addition to traditional metal and engineering works industries of the area.

In addition, strong leadership based on clear objectives was found essential and cities can bring together different stakeholders to act jointly [48]. Rogers et al. [52] also conclude based on their case study that without strong institutional support projects are unlikely to proceed even if they gain public acceptance. Cities should also provide financial and advisory support for project development. According to the interviews, in Vaasa the city has supported the efforts of the renewable energy industries in the area but the main driving actor and coordinator is the energy technology businesses of the area. The businesses, education institutions and research institutions have made a brand called EnergyVaasa; this seems to be a joint effort to market and create cooperation between the different energy actors in the Vaasa area [47]. Therefore there seems to be no single institution in Vaasa leading the development, the main institutions and businesses are in cooperation. According to the interviews in Joensuu the provincial government seems to be the main coordinator in increasing renewable energy in the area; this conclusion was supported also by the supporting documents. It was also mentioned that renewable energy actors in the Joensuu area are interested in cooperation and this has been beneficial for the development of renewable energy. There also seems to be tacit knowledge and cross-generational knowledge in the area of Joensuu. The experts interviewed were from families were forestry had been important when they were children [1].

Local renewable energy production can generate income and diversify the sources of income. It can also have positive psychological effect by providing development alternatives on isolated rural communities. Other benefits are for example that renewable energy can increase local production of energy, secure the local energy supply, save money and energy, create local jobs and involve local stakeholders $[50,51]$. In the case studies it seems that the renewable energy is important on the level of local development. Local actions can support national and international climate goals and promote sustainable urban development $[50,51]$. This was found in the supporting documents in Joensuu and Vaasa.

In the city strategies and provincial strategies of Joensuu and North Karelia bioenergy was mentioned to be the number one strategy of the area [42-46]. In the area of Ostrobothnia the first focus area is strengthening international business by helping make businesses more visible internationally and nationally [41]. The provincial strategy also mentions entrepreneurship, business, energy technology and the metal industry as being important for the area. These seem to be the main focus areas according to the interviews and the supporting documents [41].

Del Rio et al. [49] state that even if renewable energy projects can have contribution to the sustainability of rural communities, they should be viewed mostly as energy policy and not as a solution (at least not the only one) to serious socioeconomic problems of the area. According to the interviews in Joensuu the main motivation for changing oil heating into district heating with wood chips was to 
save money. So it seems that the starting point was mainly an energy political approach as Del Rio et al. [49] has stated. According to the interviews in Vaasa the main motivation was business, energy policy or the environment did not seem to be important when they started their emphasize in energy technology business. The financial report of the city of Vaasa states that the area of Vaasa is the source of $30 \%$ of Finland's energy technology exports, has 120 businesses in energy technology, employs now 10000 people and the total annual business turnover is 4 billion euros [39].

The city strategy and financial strategy indicates that energy technology, education in energy and giving support to these industries is the main focus point for Vaasa [39, 40]. In Joensuu there has been benefits related to local policy in the renewable energy business. Bioenergy and the forestry employ 6000 people in 500 companies and the annual turnover is 1,7 billion euros [45]. As Del Rio et al. [51] and Martinot et al. [50] have also concluded bioenergy has not solved all the problems in the local economy but it has helped in creating hope and creating new possibilities for North Karelia and Joensuu.

\section{Conclusions}

After liberalization of electricity markets, many electricity suppliers have started to compete also on other attributes than price. As a result,various kinds of green electricity products, marketed as environmentally friendly, are offered to customers. The coexistence of renewable energy policies and voluntary mechanisms to support renewable energy use can create problems. Issues, such as double counting of renewable energy or generating green energy only by already existing power plants, can limit the actual additional environmental impacts of voluntary green energy markets.

The demand for green electricity products has developed differently in the studied countries: unlike in the UK and Finland, in Germany the demand has increased significantly and is also relatively high. Results show that the ranges of the price premiums are wide and depend on factors like electricity consumption and region for example. Typically the mean premiums are in the range of $0-5 \%$ but green electricity products can also be cheaper than the standard electricity products.

In the case studies of Joensuu and Vaasa it seems that taking into account the socio-economic structure of the area and the people in the area can be beneficial for increasing renewable energy and making opinions towards renewable energy more positive. Benefits to the local area can make people more interested and willing to invest in renewable energy. For this to happen it seems that the area must be open to outside world, expertise in a field that is relevant to the renewable energy technology, innovative and there must be cooperation, also leadership seems to be important.

\section{References}

[1] A. Hast, L. McDermott, S. Syri, M. Järvelä, Proceedings of ICCE 2013: International Conference \& Exhibition on Clean Energy, September 9-11, 2013, Ottawa, 131-143

[2] J. Kaenzig, S. Heinzle, R. Wüstenhagen, Energy Policy 53, 311-322 (2013)

[3] R. Wüstenhagen, M. Bilharz, IWOe Discussion Paper No 111 (2004)

[4] Directive 2009/28/EC, The European Parliament and the Council of the European Union, Official Journal of the European Union 140/16 (2009)

[5] Directive 2003/54/EC, The European Parliament and the Council of the European Union, Official Journal of the European Union 176/37 (2003)

[6] DECC, Increasing the use of low-carbon technologies, (2013) https://www.gov.uk/ government/policies/increasing-the-use-of-low-carbon-technologies/ supporting-pages/the-renewables-obligation-ro

[7] Act on granting priority to renewable energy sources (Renewable Energy Sources Act - EEG), (2012)

[8] Finlex,Laki uusiutuvilla energialähteillä tuotetun sähkön tuotantotuesta, 1396/2010 (2010) 
[9] I. Diaz-Rainey, J. Ashton, Energy Policy 36, 3053-3061 (2008)

[10] Ofgem, Going green with your electricity use (2009): http://www.ofgem.gov.uk/ Media/FactSheets/Documents1/greentariffsfs.pdf

[11] V. Graham, Reality or Rhetoric? Green Tariffs for Domestic Consumers,National Consumer Council (2007)

[12] BMU, Electricity from Renewable Energy Sources - What does it cost? (2009)

[13] E. Wagner, Ökostrom-Tarife Was sinddiese, was bewirkendiese? (2008)

[14] U. Leprich, Fokus Ökostrom: Bestandsaufnahmeund Perspektiven (2008)

[15] T. Närvä., M. Pakkanen,Vihreän sähkön tarjonta Suomen sähkömarkkinoilla (2010)

[16] B. Truffer, J. Markard, R. Wüstenhagen, Energy Policy 29, 885-897 (2001)

[17] L. Bird, R. Wüstenhagen, J. Aabakken, Renew. Sustain. Energy Rev. 6, 513-536 (2002)

[18] S.Batley, D. Colbourne, P. Fleming, P. Urwin, 2001. Energy Policy 29, 479-487 (2001)

[19] R.Wiser, Utilities Policy 7, 107-119 (1998)

[20] S. Salmela, V. Varho, Energy Policy 34, 3669-3683 (2006)

[21] J. Lipp, Renewable Energy 24, 31-44 (2001)

[22] Ofgem, Domestic Retail Market Report - June 2007, 169/07 (2007)

[23] Ofgem, Sustainable Development indicators- Theme 1: Managing the transition to a low carbon economy (July 2012)

[24] R. Wüstenhagen, M. Bilharz, Energy Policy 34, 1681-1696 (2006)

[25] EKOenergy (2013): http://www.ekoenergy.org/

[26] Eurostat (2013): http://epp.eurostat.ec.europa.eu/tgm/table.do?tab=table\&init= 1\&plugin=1\&language $=$ en\&pcode $=$ tps 00001

[27] R. MacPherson, I. Lange, Stirling Economics Discussion Paper 2012-11 (2012)

[28] I. Diaz-Rainey, D. Tzavara, Technol. Forecast. Soc. Change 79, 1693-1704 (2012)

[29] Ofgem, Consumer attitudes and awareness of green issues and energy (2008)

[30] R. Mewton, O. Cacho, Energy Policy 39, 377-385 (2011)

[31] M. Kotchen, M. Moore. J. Environ. Econ. Manag. 53, 1-16 (2007)

[32] http://energyapps.consumerfocus.org.uk/price/

[33] http://www.greenelectricity.org/index.php

[34] http://www.strompreisvergleich.net/

[35] http://www.verivox.de/

[36] www.strompreisvergleich-24.de

[37] http://www.sahkonhinta.fi/

[38] http://www.vaasaemg.com/

[39] Vaasa, Talousarvio 2013, Taloussuunitelma 2013-2015 (Financial plan and assesment of Vaasa 2013-2015) (2012) Approved by the city council of Vaasa 10.12.2012. Electronic pdf document. http://www.vaasa.fi/Link. aspx?id=1242188

[40] Vaasa, Pohjolan energiapääkaupunki - virtaa hyvään elämään. (2013) Approvedby the city council of Vaasa 17.6.2013. Electronic pdf document. http://www.vaasa.fi/ Link . aspx?id $=1248750$

[41] RCO (Regional Council of Ostrobothnia), Pohjanmaanmaakuntaohjelma (Regional strategy of Ostrobothnia) (2011) electronic pdf document. http://www . obotnia.fi/fi/binaryviewer. aspx?MediaID $=5186$

[42] PKML, Pohjois-KarjalanmaakuntaliittoItä-Suomenbioenergiaohjelma 2020 (bioenergy program of North Karelia) (2012) pdf document. http://www.pohjois-karjala.fi/dman/ Document $\cdot$ phx?document Id=zp36111100930357\&cmd=download

[43] PKML,Pohjois-Karjalan ilmasto- ja energiaohjelma. (Climate and Energy Energy Programme of North Karelia) (2012) pdf document. http://www.pohjois- karjala.fi/dman/ Document $\cdot$ phx?document Id=he24911143754662\&cmd=download 
$3^{\text {rd }}$ European Energy Conference

[44] PKML,Toiminta- ja taloussuunnitelma 2013-2015 sekä tulostavoitteet ja talousarvio (Financial and action strategy 2013.2015 and budjet and budjet goals) (2013) pdf document. http://www . pohjoiskarjala.fi/dman/Document . phx?documentId=xb00713144310820 \&cmd=downlo ad

[45] JNS, Kestävästi kasvava älykkäästi uusiutuva. Joensuun kasvustategia (Growth Strategy of Joensuu) (2012) Pdf document. http://www.pohjois-karjala.fi/dman/Document.phx/ maa-kuntaliitto/Julkiset/Tiedotus/Joensuun+kasvustrategia?folderId= maakuntali-itto\%2F Julkiset $\% 2$ FTiedotus\&cmd=download

[46] JNS, Joensuunkansainvälistymisstrategia. (International strategy of Joensuu) (2010) http://www. joensuu.fi/documents/11127/257171/Kansainv\%C3\%A4lisyystrategia +2009+- +2015/f342ee60-ff75-4763-bd20-3af90ef $31 \mathrm{f} 43$

[47] EnergyVaasa (2013): http://www .energyvaasa.fi/

[48] IEA/OECD, Cities, towns \& renewable energy, yes in my front yard (2009)

[49] P. Del Rio, M. Burguillo,Renew. Sustain. Energy Rev. 13, 1314-1325 (2009)

[50] E. Martinot et al., Global Status Report on Local Renewable Energy Policies (2011)

[51] P. Del Rio, M. Burguillo,Renew. Sustain. Energy Rev. 12, 1325-1344 (2008)

[52] J. Rogers, E. Simmons, I. Convery, A. Weatherall, Energy Policy 36, 4217-4226 (2008) 